\title{
Autoantibody profiling in systemic lupus erythematosus
}

This article was published in the following Dove Press journal:

Current Biomarker Findings

22 August 2013

Number of times this article has been viewed

\author{
Song-Chou Hsieh' \\ Chia-Li Yu ${ }^{1,2}$ \\ 'Department of Internal Medicine, \\ ${ }^{2}$ Institute of Molecular Medicine, \\ National Taiwan University College \\ of Medicine, Taipei, Taiwan
}

\begin{abstract}
Systemic lupus erythematosus (SLE) is an archetype of systemic autoimmune disease characterized by the production of a broad spectrum of autoantibodies. More than 100 autoantibodies have been found in the sera of patients with SLE, including antibodies against nuclear, cytoplasmic, surface-membrane, and extracellular antigens. There has been considerable debate as to whether these antinuclear autoantibodies (ANAs) are merely biomarkers for disease or are responsible for organ/tissue damage in SLE. In recent years, sufficient evidence has supported the hypothesis that many ANAs, such as anti-double-stranded DNA (anti-dsDNA), antiribosomal P, anti-Sm, antiribonucleoprotein (anti-RNP), and even anti-Sjögren's syndrome (SS)-B/La antibodies not only act against specific nuclear antigens but also cross-react with different surface-expressed cognate molecules. The binding of autoantibodies to the cell surface leads to their penetration into the cell's interior to elicit cellular damage. There are at least four conceivable routes for ANAs to penetrate the cytoplasm: (1) nonspecific Fc $\gamma$ receptor-mediated uptake, (2) cell-surface caveolae-mediated endocytosis, (3) electrostatic interactions between positively charged amino acids of the complementarity-determining regions of the antibody molecule and the negatively charged surface membrane, and (4) the binding of the autoantibody with its cross-reactive cell surface-expressed cognate molecule, and its subsequent endocytosis into the cytoplasm. In this review, we discuss in detail the immunopathogenic mechanisms of the commonly encountered ANAs, such as anti-dsDNA, antiribosomal P, and anti-SSB/La, that are associated with lupus pathogenesis. Additionally, the detrimental thromboembolisminducing anticardiolipin antibodies in patients with SLE were found to not only damage vascular endothelial cells, red blood cells, and platelets but also suppress lymphocyte proliferation, neutrophil phagocytosis, glomerular mesangial cell growth, and brain damage through their nonspecific membranotropic effects. For future clinical applications, useful biomarkers in SLE sera should be identified to determine disease susceptibility, diagnosis, activity evaluation, and specific organ damage.
\end{abstract}

Keywords: systemic lupus erythematosus, pathogenic autoantibody, cross-reactivity, autoantibody penetration, lupus pathogenesis, neuropsychiatric SLE

\section{Introduction}

Systemic lupus erythematosus (SLE) is an archetype of chronic autoimmune disease with inflammation in various organs/tissues, especially the musculoskeletal, mucocutaneous, renal, and nervous systems (Table 1, our unpublished data). More than 100 different autoantibodies have been found in the serum of patients with SLE. ${ }^{1}$ It is conceivable that the wide spectrum of clinical manifestations in patients with SLE is partially caused by pathogenic autoantibodies. The autoantibodies may potentially target their corresponding autoantigens in the cell nuclei, cytoplasm, cell-surface membrane,
Department of Internal Medicine National Taiwan University Hospital, 7 Chung-Shan South Road, Taipei 100 Taiwan

Tel +886 223 I 23456 ext 650 I I

Fax +88622395 780I

Email chialiyu@ntu.edu.tw submit your manuscript $\mid$ www.dovepress.com

Dovepress

http://dx.doi.org// 0.2147/CBF.S34496 
Table I Organs/tissues affected in patients with systemic lupus erythematosus (Hsieh and Yu, unpublished data, 2013)

\begin{tabular}{ll}
\hline Organ/tissue & Involvement \\
\hline Musculoskeletal & $90 \%$ \\
Oral mucous ulcer & $30 \%$ \\
Skin & \\
Photosensitivity & $25 \%$ \\
Malar skin erythema & $50 \%$ \\
Discoid lesions & $10 \%$ \\
Alopecia & $20 \%$ \\
Raynaud's phenomenon & $25 \%$ \\
Pleuropericarditis & $40 \%$ \\
Kidney & $65 \%$ \\
Neuropsychiatric lesions & $15 \%$ \\
Hematology & \\
Leukopenia & $46 \%$ \\
Anemia & $42 \%$ \\
Thrombocytopenia & $35 \%$ \\
\hline
\end{tabular}

serum components, extracellular matrix substances, and miscellaneous molecules. The mechanism of production of the diverse spectrum of autoantibodies against self-antigens remains to be elucidated. However, many studies have demonstrated that autoantibody production might be antigendriven, ${ }^{2}$ a result of polyclonal B-cell activation, ${ }^{3}$ impaired apoptotic cell clearance, ${ }^{4}$ or idiotypic network dysregulation in patients. ${ }^{5}$ It is quite possible that polyclonal B-cell activation in SLE is derived from (1) defective B-cell tolerance in the bone marrow, ${ }^{6}(2)$ somatic hypermutation during the germinal center reaction, ${ }^{2}$ (3) B-cell epitope spreading after chronic stimulation, ${ }^{7}$ and (4) impaired apoptotic cell clearance by phagocytes. These mechanisms can lead to nuclear antigen-driven autoantibody production. ${ }^{8}$ On the other hand, increased cell destruction in patients with SLE by either cellular or antibody-mediated mechanisms concomitant with defective apoptotic cell clearance becomes a vicious cycle of the chronic immune dysfunction found in patients with SLE (Figure 1). The increased cell apoptosis or eventual secondary necrosis in addition to defective cell debris clearance does not merely break down self-tolerance but also stimulates both innate and adaptive immune responses to induce florid autoantibody production. There are at least three defects involved in decreased apoptotic cell clearance in SLE: (1) congenital deficiency of complement components $\mathrm{C} 2, \mathrm{C} 4$, or $\mathrm{C} 1 \mathrm{q},{ }^{9}$ (2) production of autoantibodies against $\mathrm{C}$-reactive protein and other acute-phase proteins, ${ }^{10}$ and (3) production of anti-heat shock-protein autoantibodies. ${ }^{11}$ The aforementioned molecules are crucial for tissue-debris opsonization and facilitate phagocytosis of the opsonized tissue debris or nuclear substances. Defective cell debris molecules engulfed by phagocytes eventually cause these denatured autoantigens to activate the innate and adaptive immune systems to produce autoantibodies.

Many studies have demonstrated that at least two unique properties are found in naturally occurring and pathogenic immunoglobulin (Ig) G autoantibodies compared to nonspecific IgGs: (1) polyreactivity or cross-reactivity results in an autoantibody being reactive with many different antigens, ${ }^{12-15}$ and (2) penetration of these antigen-driven autoantibodies into the cell interior. ${ }^{16}$ Prabhakar et a ${ }^{12}$ were the first authors to demonstrate that normal human B lymphocytes are capable of producing monoclonal autoantibodies reactive to different tissues/organs. Hurez et a $1^{13}$ further demonstrated that polyreactivity or cross-reactivity is a characteristic of naturally occurring autoantibodies in the serum. In the physiological sense, these low-titer natural antibodies in the serum work as first-line defense molecules against microbial infections. However, an increasing number of observations have found that polyreactive autoantibodies in different autoimmune disorders indeed possess pathogenic potential to cause cell/ tissue damage. ${ }^{14,15}$ Many authors have demonstrated that the third complementarity-determining region (H-CDR3) of the immunoglobulin heavy chain and the N-terminal region contribute to differences in polyreactivity and monospecificity between natural and antigen-driven antibodies, respectively. ${ }^{17-19}$ Weller et $\mathrm{al}^{20}$ further demonstrated that terminal deoxynucleotidyl transferase can mediate N-region diversity (polyreactivity) and affect the affinity of anti-DNA autoantibodies in mice.

Alarcón-Segovia et $\mathrm{al}^{21}$ were the first to demonstrate that the penetration of autoantibodies into cells may induce autoimmune disease via cell damage and immune dysregulation. The same group further reported that most anti-DNA antibodies penetrate large proportions of live immature cells, and not normal adult cells, to elicit cell apoptosis. ${ }^{22}$ Although pathogenic autoantibodies play an important role in cell/tissue damage, many other factors derived from abnormal immune responses, including proinflammatory cytokines (interleukin [IL]-1 $\beta$, IL-6, IL-8, IL-17, tumor necrosis factor [TNF]- $\alpha$, different colony-stimulating factors, and macrophage-stimulating factors), $\mathrm{O}_{2}$ radicals, nitric oxide, released proteolytic enzymes, immune complexes, (ICs), and T cell-mediated autoimmune reactions, may also be implicated in lupus pathogenesis and sustain chronic tissue inflammation. Among these, complement fixed-IC-induced cell/tissue inflammation via complement receptors on the cell surface were an important pathogenic mechanism of antinuclear autoantibodies (ANAs). The IC mechanism may include IC formation in the blood (circulatory ICs) and in situ IC formation in tissues. 


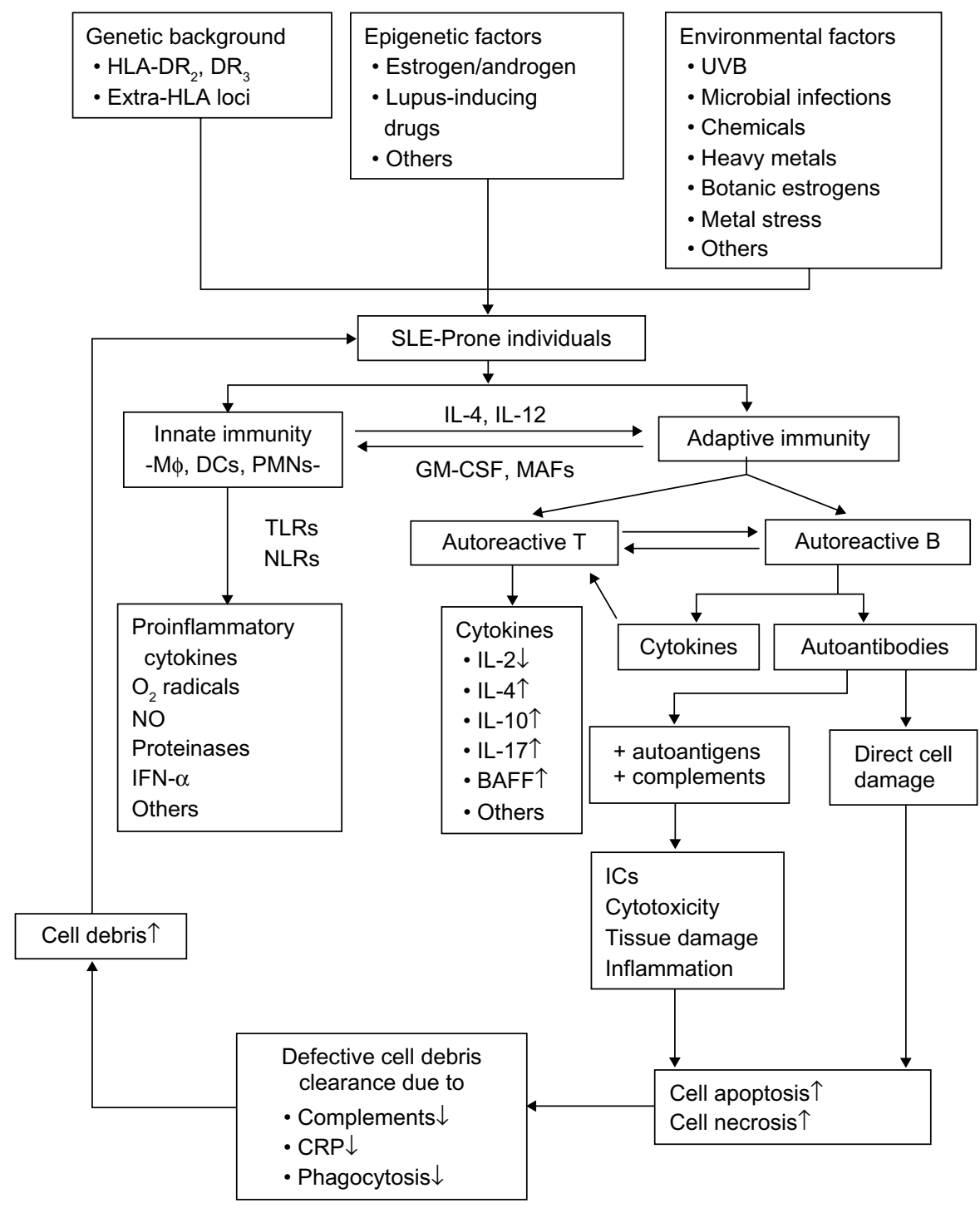

Figure I Schema depicting the etiopathogenesis of systemic lupus erythematosus.

Abbreviations: TLR, Toll-like receptor; NO, nitric oxide; NLRs, NOD-like receptor; BAFF, B cell activation factor from the tumor necrosis factor family; M $\phi$, monocytes/ macrophages; MAFs, macrophage activating factors; ICs, immune complexes; PMNs, polymorphonuclear neutrophils.

However, it is quite difficult to confirm directly the presence of autoantigens in the circulating ICs in the serum. The in situ formation of ICs also depends on surface-expressed specific autoantigens, molecular mimic antigens, or electrostatic interactions between positively charged antibodies and negatively charged molecules in the tissues. It is believed that some of the ANAs are pathogenic, whereas some of them are nonpathogenic. The conflicting results in the literature may depend on the properties of the ANAs. Only the high titer of ANAs cannot reflect the degree of tissue damage in patients with SLE. Furthermore, the clearance capacities of ICs as well as tissue debris by macrophages, dendritic cells, neutrophils, and reticuloendothelial systems in patients with SLE are defective. Therefore, excessive ICs and cell debris such as nucleosomes, denatured deoxyribonucleoproteins, and denatured ribonucleoproteins may bind to endosomal Toll-like receptors (TLR3, -7, and -9) and nucleotide-binding oligomerization domain-like receptors in the macrophage/ dendritic cells to stimulate ANA production. These potential pathogenic factors and their deleterious reactions are depicted in Figure 1.

It has been a long-standing debate as to whether the broad spectrum of autoantibodies are culprits or merely innocent bystanders as disease biomarkers in patients with SLE. ${ }^{23-27}$ Evidence supports that both possibilities coexist, because some of them are good biomarkers for disease susceptibility and diagnosis, whereas others play pathogenic roles in SLE via their cell-penetrating ability into the cytoplasm to induce cell damage (Table 2). In this review, we extensively discuss the immunopathogenic roles of the four 
Table 2 Autoantibodies that penetrate the cell interior and impair cell functions in patients with systemic lupus erythematosus

\begin{tabular}{|c|c|c|}
\hline Autoantibody & Target cell & Functional impairment \\
\hline \multirow[t]{8}{*}{ Anti-dsDNA } & Glomerular & AICD, cell \\
\hline & mesangial cells & proliferation $\downarrow$ 43,44,46,47,50 \\
\hline & Macrophages, T cells & Functional impairment $\mathrm{t}^{42,49}$ \\
\hline & Astrocytes, neuronal & \\
\hline & cells & GFAP $\downarrow^{36}$ \\
\hline & PMNs & IL-8 $\uparrow$, phagocytosis $\downarrow$, AICD $\uparrow 48$ \\
\hline & B cells & Biphasic cell proliferation ${ }^{42}$ \\
\hline & & Immunoglobulin synthesis $\uparrow 42$ \\
\hline \multirow[t]{4}{*}{ Antiribosomal P } & $\mathrm{T}$ cells & Cell proliferation $\downarrow^{69}$ \\
\hline & Macrophages & Apoptosis $\uparrow 70,71$ \\
\hline & Brain & Psychosis ${ }^{66}$ \\
\hline & Glomerular cells & Nephritis ${ }^{67,68}$ \\
\hline Anti-RNP & Mononuclear cells & Intracellular GSH $\downarrow *(\bullet)$ \\
\hline Anti-Sm & Mononuclear cells & Cell proliferation $\downarrow(\bullet)$ \\
\hline \multirow[t]{4}{*}{ Anti-SSB/La } & Cardiac AV node & Different degree AV block ${ }^{74,75}$ \\
\hline & Mononuclear cells & Cell proliferation $\downarrow^{79}$ \\
\hline & PMNs & Phagocytosis $\downarrow$, IL-8 $\uparrow 77,79$ \\
\hline & Lymphocytes & $\begin{array}{l}\text { AICD } \uparrow 79 \\
\text { AICD } \uparrow 79\end{array}$ \\
\hline
\end{tabular}

Notes: *Reduced-form GTH; •, Formasan J Rheumatol. 1994; I (3-4):33-5I. Abbreviations: dsDNA, double-stranded DNA; AICD, activation-induced cell death; GFAP, glial fibrillary acidic protein; PMNs, polymorphonuclear cells; IL, interleukin; RNP, ribonucleoprotein; GSH, glutathione; SS, Sjögren's syndrome; $\mathrm{AV}$, atrioventricular.

commonly encountered autoantibodies in clinical practice, including anti-double-stranded DNA (anti-dsDNA), anticardiolipin antibody (ACA), antiribosomal P protein (anti-RP), and anti-Sjögren's syndrome (SS)-B/La antibodies in lupus pathogenesis.

\section{Different autoantibodies can be used as specific biomarkers of SLE in different clinical categories}

In 1997, the American College of Rheumatology revised the classification criteria for SLE, suggesting that anti-dsDNA, ACA, and anti-Sm antibodies can be used as diagnostic biomarkers for SLE. ${ }^{28}$ In daily practice, the titer of anti-dsDNA, antinucleosome, and antinucleoside/antinucleotide antibodies, if applicable, can be used as disease-activity biomarkers in SLE. ${ }^{1,29,30}$ These autoantibody biomarkers are more convenient in daily practice than complex global evaluation scores, such as the SLE Disease Activity Index ${ }^{31}$ or the British Isles Lupus Activity Group assessment ${ }^{32}$ for evaluating SLE serological changes, but not for systemic tissue/organ-damage evaluation. Undoubtedly, many autoantibodies are regarded as surrogate biomarkers for specific organ/tissue damage in patients with SLE. Table 3 lists some of the potential autoantibody biomarkers used in different clinical categories of patients with SLE. Among these, anti-dsDNA antibodies can
Table 3 Potential autoantibody biomarkers used in different clinical settings for systemic lupus erythematosus

\begin{tabular}{|c|c|}
\hline Category & Autoantibody \\
\hline \multirow[t]{3}{*}{ Disease diagnosis } & Anti-dsDNA ${ }^{28}$ \\
\hline & Anti-Sm ${ }^{28}$ \\
\hline & Anticardiolipin ${ }^{28}$ \\
\hline \multirow[t]{5}{*}{ Disease activity } & Anti-dsDNA ${ }^{1,28,55}$ \\
\hline & Antinucleosome $\mathrm{e}^{29}$ \\
\hline & Antinucleosides/nucleotides ${ }^{29,30}$ \\
\hline & Anti-Clq $q^{33-35}$ \\
\hline & Antiacidic ribosomal $\mathrm{P}^{49,76}$ \\
\hline \multicolumn{2}{|l|}{ Specific organ damage } \\
\hline \multirow[t]{7}{*}{ Nephropathy } & Anti-dsDNA ${ }^{43-48,51}$ \\
\hline & Antinucleosome ${ }^{29}$ \\
\hline & Anti-Clq $q^{34}$ \\
\hline & Anticardiolipin ${ }^{73}$ \\
\hline & Anti-SSA/Ro ${ }^{82,83}$ \\
\hline & Antiribosomal $P^{75}$ \\
\hline & Anti-glomerular matrix ${ }^{*, 93}$ \\
\hline \multirow[t]{3}{*}{ Dermatitis } & Antiribosomal P75,76 \\
\hline & Anti-SSA/Ro $0^{82,83}$ \\
\hline & Anti-SSB/La $a^{82,83}$ \\
\hline \multirow[t]{2}{*}{ Vasculitis } & Anti- $\alpha$-enolase ${ }^{95}$ \\
\hline & Anticardiolipin ${ }^{65}$ \\
\hline \multirow[t]{5}{*}{ NPSLE } & Antineuronal NR2 $2 *, 36,80$ \\
\hline & Antiribosomal $\mathrm{P}^{74}$ \\
\hline & Anticardiolipin ${ }^{72,73}$ \\
\hline & Antiendothelial ${ }^{77}$ \\
\hline & Anti-dsDNA ${ }^{36}$ \\
\hline \multicolumn{2}{|l|}{ Hematology } \\
\hline Hemolytic anemia & Anti-RBC, anticardiolipin ${ }^{72}$ \\
\hline \multirow[t]{3}{*}{ Neutropenia } & Antineutrophil, anti-SSB/La ${ }^{87,88}$ \\
\hline & Anti-dsDNA ${ }^{52}$ \\
\hline & Anticardiolipin ${ }^{71}$ \\
\hline \multirow[t]{4}{*}{ Lymphopenia } & Antilymphocyte, anti-SSB/ $\mathrm{La}^{87,88}$ \\
\hline & Anti-dsDNA ${ }^{53,54}$ \\
\hline & Antiribosomal $\mathrm{P}^{71,77}$ \\
\hline & Anticardiolipin ${ }^{71}$ \\
\hline Thrombocytopenia & Antiplatelet, anticardiolipin ${ }^{58-63}$ \\
\hline Thromboembolism & Anticardiolipin ${ }^{58-63}$ \\
\hline Habitual abortion and fetal loss & Anticardiolipin ${ }^{58-63}$ \\
\hline
\end{tabular}

Notes: *Anti- $\alpha$-actinin, antilaminin, antifibronectin, antimyosin, and anticollagen; **anti-N-methyl-D-aspartate receptor subtypes $2 \mathrm{a}$ and $2 \mathrm{~b}$ on neuronal cells.

Abbreviations: dsDNA, double-stranded DNA; SS, Sjögren's syndrome; NPSLE, neuropsychiatric systemic lupus erythematosus; RBC, red blood cell.

be used as specific biomarkers for disease diagnosis, disease activity, and lupus nephritis. Anti-C1q autoantibodies can be used for concurrent evaluation of both renal ${ }^{33}$ and extrarenal ${ }^{34}$ disease activity in SLE. However, anti-C1q antibodies can also be detected in sera from patients with hypocomplementemic urticarial vasculitis. ${ }^{35}$ Consequently, the sensitivity and specificity of anti-C1q antibodies in evaluating SLE disease activity should be reconsidered.

One particular pathogenic autoantibody can exert deleterious effects on different organs or tissues via cross-reactivity. A representative example demonstrates that anti-dsDNA 
can induce nephritis, hepatitis, neutropenia, lymphopenia, and even neuropsychiatric lupus (NPSLE) in patients with SLE. 1,22,26,36 Conversely, an organ/tissue can be the target of different kinds of autoantibodies. NPSLE in patients with SLE is the typical case in which the organs are attacked by at least four types of autoantibodies, including antineuronal, antiribosomal $\mathrm{P}$, anticardiolipin, and antiendothelial cell antibodies. Diamond and Volpe ${ }^{36}$ demonstrated that anti-dsDNA and antipeptides bind $N$-methyl-D-aspartate (NMDA) receptor 2 (NR2) on neurons can directly mediate NPSLE, but they do not depend on IC formation when the blood-brain barrier is impaired. Obviously, the crossreactivity of an ANA can directly mediate cell/tissue damage through cell surface-expressed cognate antigens in systemic autoimmune diseases. ${ }^{37}$ Table 4 shows that polyclonal or monoclonal anti-dsDNA autoantibodies bind to different surface-expressed cognate molecules via cross-reactivity, electrostatic interactions with structural proteins, or other undefined mechanism(s) to exert different immunopathogenic effects in patients with SLE.

Autoantibody testing has been commonly used in the diagnosis and follow-up evaluation of patients with systemic rheumatic diseases. More detection methods have been developed in addition to the classical immunofluorescence anti-nuclear antibody test by using HEp-2 as the cell substrate and Western blotting. Enzyme-linked immunosorbent assay (ELISA) and an automatic bead-based ANA screening assay were successively applied for autoantibody quantification in clinical practice. Many authors found that the measurement of autoantibodies by using automatic multiplex methodology in

Table 4 Molecules that cross-react with anti-dsDNA autoantibodies expressed on the cell surface, extracellular matrix, or serum protein, and their mode of interaction

\begin{tabular}{ll}
\hline Molecules & Target/mode of interaction \\
\hline Heparan sulfate & Glomerular matrix/electrostatic interactions \\
Chondroitin sulfate & Glomerular matrix/electrostatic interactions \\
Ribosomal P0, PI, & Surface-expressed antigen on different \\
and P2 & cells/cross-reactivity ${ }^{43,44,49}$ \\
$\alpha$-Actinin & Glomerular mesangial cells/cross-reactivity \\
$\alpha$-Enolase & Glomerular mesangial cells, \\
& epithelial cells/cross-reactivity \\
Annexin II & Glomerular mesangial cells, \\
& epithelial cells/cross-reactivity \\
Fibronectin & Glomerular matrix/cross-reactivity \\
Laminin & Glomerular matrix/cross-reactivity \\
Collagen & Glomerular matrix/cross-reactivity \\
$\beta_{2}$ GPI & Serum protein/cross-reactivity \\
Phospholipids & Surface-expression on different \\
& cells/cross-reactivity
\end{tabular}

Abbreviations: GPI, glycoprotein I; dsDNA, double-stranded DNA. patients with SLE was equally sensitive and highly specific compared to conventional ELISA. ${ }^{38-40}$ Recently, Eriksson et $\mathrm{al}^{41}$ found that autoantibodies against nuclear antigens, particularly SSA/Ro and dsDNA, could be detected before the onset of SLE. The first autoantibody detected was anti$\mathrm{SSA} / \mathrm{Ro}$, and the highest predicted odds ratio was conferred by anti-dsDNA antibodies.

\section{Immunopathogenic roles of anti-dsDNA antibodies in lupus pathogenesis}

Polyclonal anti-dsDNA antibodies purified from active SLE sera by $\lambda$-phage DNA-affinity chromatography suppress mitogen-activated T-lymphocyte proliferation, but elicit biphasic immunoglobulin synthesis by activated $\mathrm{B}$ lymphocytes, as shown in our previous study. ${ }^{42}$ These functional changes by anti-dsDNA antibodies resemble immune disorders in patients with SLE. SLE-derived polyclonal anti-dsDNA antibodies were also shown to be nephrotropic and could directly damage the glomerular mesangial cells (GMCs) through binding to the surface-expressed acidic ribosomal phosphoproteins P0 (38 kDa), P1 (19 kDa), and P2 (17 kDa). ${ }^{43,44}$ These results are partially consistent with the findings by $\mathrm{Du}$ et $\mathrm{al},{ }^{45}$ indicating that nine affinitypurified anti-dsDNA autoantibodies cross-reacted with cell membrane-expressed $74 \mathrm{kDa}, 63 \mathrm{kDa}$, and $42 \mathrm{kDa}$ molecules. Yung et $\mathrm{al}^{46,47}$ demonstrated that anti-dsDNA antibodies bound to annexin II molecules on human GMCactivated p38 mitogen-activated protein kinase (MAPK), Jun, AKT, protein kinase $C-\alpha$, and protein kinase $C-\beta$ signaling pathways to induce IL-6, transforming growth factor- $\beta_{1}$, fibronectin, and annexin II synthesis. In contrast, Fenton et $\mathrm{a}^{48}$ suggested that chromatin in circulating blood is important for glomerular mesangial matrix IC deposition for the occurrence of lupus nephritis. In addition to lupus nephritis, we found that anti-dsDNA autoantibodies also targeted P0 and P1 molecules expressed on different tissues of normal and autoimmune mice, such as in the liver, spleen, brain, and fibroblasts. ${ }^{49}$ The cross-reactivity between anti-dsDNA and surface-expressed $\mathrm{P} 1$ protein relies on the $\mathrm{C}$-terminal hydrophobic cluster region containing a phenylalanine residue..$^{50}$ Interestingly, a monoclonal anti-DNA antibody was shown to penetrate immature lymphoid cells more than their mature counterparts, and induced cell apoptosis, self-tolerance, or an autoimmune response depending upon the degree of immune dysregulation..$^{21,22}$ These findings may become the molecular basis of the positive correlation between serum titers of antidsDNA and disease activity of SLE. ${ }^{49}$ Functional assessments 
revealed that anti-dsDNA upregulates $I L 6$ gene expression ${ }^{51}$ and fibronectin synthesis ${ }^{46}$ in GMCs, and can be used as an indicator for immune-mediated renal damage. Hsieh et $\mathrm{al}^{52}$ reported that monoclonal anti-dsDNA antibodies bound to human neutrophils upregulated IL8 gene expression and finally elicited activation-induced cell apoptosis. Luan et $\mathrm{al}^{53}$ and Song et $\mathrm{al}^{54}$ demonstrated that a monoclonal anti-dsDNA antibody inhibited IL2 gene expression in a Jurkat T-cell line by activating phosphorylated glycogen synthase kinase 3 , which mimics T-cell hyporesponsiveness in patients with active SLE. ${ }^{42}$ Genetic manipulation by transgenic overexpression of anti-dsDNA autoantibodies and TLR4 activation in mice induced severe SLE syndrome. ${ }^{55}$

Despite the cross-reactivity of anti-dsDNA antibodies with surface-expressed cognate molecules, it remains possible that the binding of anti-dsDNA to the cell surface is mediated by electrostatic interactions between the positively charged arginine residues in the CDRs of the IgG antibody F(ab')2 domain with the negatively charged surface membrane. ${ }^{56}$ Alternatively, the IgG isotype autoantibody nonspecifically binds to the Fc $\gamma$ receptor on the cell surface, and subsequently the ligand-receptor conjugates are taken up by endocytosis. ${ }^{57}$ A schematic illustration of the immunopathogenic effects of anti-dsDNA on lupus pathogenesis is shown in Figure 2.

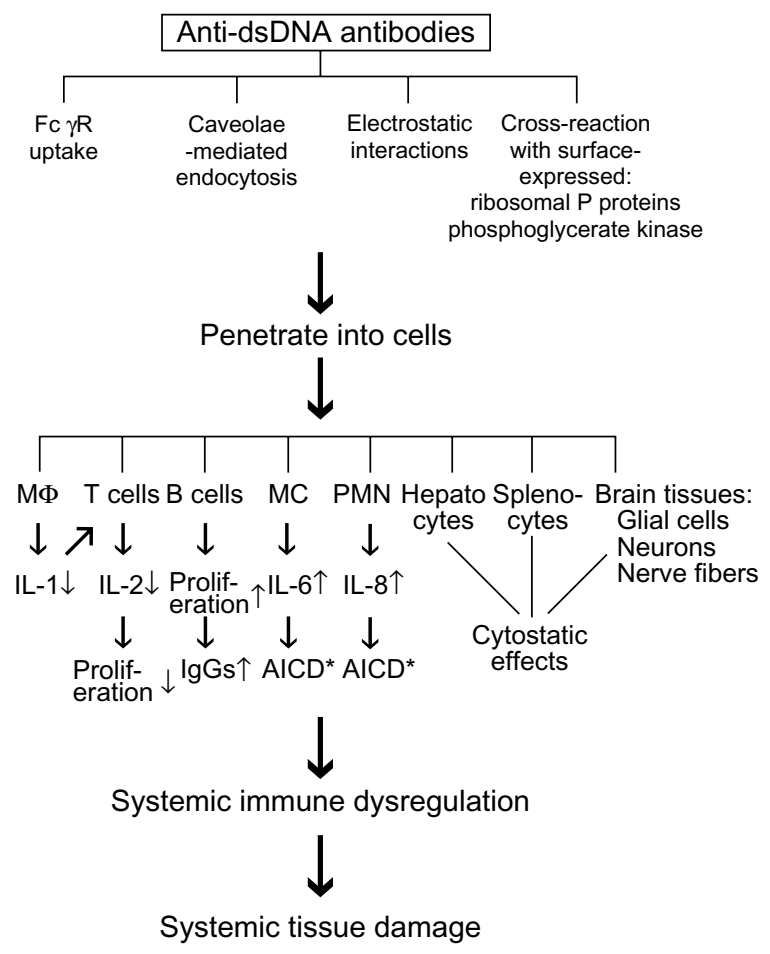

Figure 2 Schema depicting the immunopathogenic roles of anti-dsDNA autoantibodies on lupus pathogenesis.

Note: *AICD: activation-induced cell death (apoptosis).

\section{Immunopathogenic roles of anticardiolipin antibodies on brain damage and immune dysfunctions in patients with SLE}

It is conceivable that antiphospholipid antibodies (aPLs) contain anti-cell surface phospholipids, such as phosphatidylcholine, phosphatidylserine, and phosphatidyl-ethanolamine (detected by ELISA); anticardiolipin antibodies (detected by ELISA); and lupus anticoagulants (detected by their ability to prolong certain in vitro phospholipid-restricted bloodclot tests). Pathogenic aPLs are catastrophic autoantibodies that induce antiphospholipid syndrome (APS), which is relevant to a broad spectrum of thromboembolic disorders, hematological cytopenia, and habitual abortion in patients with SLE. ${ }^{58-63}$ Pathogenic aPLs can bind to both PLs and plasma cofactors, among which $\beta_{2}$-glycoprotein I ( $\left.\beta_{2} \mathrm{GPI}\right)$ is the most crucial factor. In an animal model, anti- $\beta_{2}$ GPI antibodies from patients with antiphospholipid syndrome were sufficient to potentiate arterial thrombus. ${ }^{64}$ In contrast, influenza vaccination was shown to induce anticardiolipin but not $\beta_{2}$ GPI antibodies, and was not found to be pathogenic to the patients..$^{65}$ Annexin A5 is an important member of the annexin family with antithrombotic properties. This molecule has been implicated in SLE, because aPL interferes with its functions and causes thromboembolism and miscarriages in patients with SLE. ${ }^{66,67}$

Lin et $\mathrm{a}^{68}{ }^{6}$ reported that some aPLs recognized conformational epitopes shared by $\beta_{2}$ GPI and the homologous catalytic domains of many serine proteases. In a series of investigations on thrombotic mechanisms elicited by aPLs, Meroni et a ${ }^{69}$ found that sophisticated processes were involved. These processes included disruption of fluid-phase coagulation, disruption of coagulation cell functions, and complement activation. Subsequently, Misra et al ${ }^{70}$ determined that the activation of lymphocytes was mandatory for the expression of binding epitopes for ACAs on the cell surface. We purified ACAs from $\mathrm{ACA}^{+}$SLE sera following their methodology, and found that these particular autoantibodies possessed inhibitory activities on lymphocyte proliferation and polymorphonuclear cell (PMN) phagocytosis. ${ }^{71}$ Furthermore, these SLE-derived ACAs bound to a rat brain astrocyte cell line and inhibited their proliferation in an in vitro experiment. ${ }^{72}$ Surprisingly, intravenously injected ACAs entered brain tissue and bound to neurons, glial cells, and nerve fibers in an in vivo study. ${ }^{73}$ These observations suggest that ACAs possess a potential capacity to damage the blood-brain barrier, penetrate brain tissue, and exert deleterious effects in NPSLE. ${ }^{72}$ 
Tsai et $\mathrm{al}^{73}$ also demonstrated that ACAs induced apoptosis of GMCs in addition to vascular coagulopathy in lupus nephropathy. Taking these findings together, we can conclude that ACAs exert potent immunosuppressive effects and play a role in NPSLE through their nonspecific membranotropic properties. A proposed schema illustrating the immunopathogenic effects of ACAs on lupus tissue damage is shown in Figure 3.

\section{Immunopathogenic effects of antiribosomal $\mathbf{P}$ autoantibodies on lupus psychosis and T-lymphocyte derangement}

Autoantibodies against acidic ribosomal $\mathrm{P}$ have been demonstrated in $13 \%-20 \%$ of patients with SLE, and levels correlated with psychosis, nephritis, hepatitis, skin manifestations, and general disease activity. ${ }^{74-76}$ However, their effects on immune functions and the molecular basis for their activities have not been elucidated.

Sun et $\mathrm{al}^{77}$ reported that a monoclonal anti-human ribosomal $\mathrm{P}$ protein was involved in the pathogenesis of lymphopenia and lymphocyte dysfunction in SLE by penetrating living cells. The same group further demonstrated that this monoclonal antibody inhibited the release of IL-12, TNF- $\alpha$, and inducible nitric oxide synthase in an activated mouse RAW 264.7 macrophage cell line. ${ }^{78}$ In contrast, the

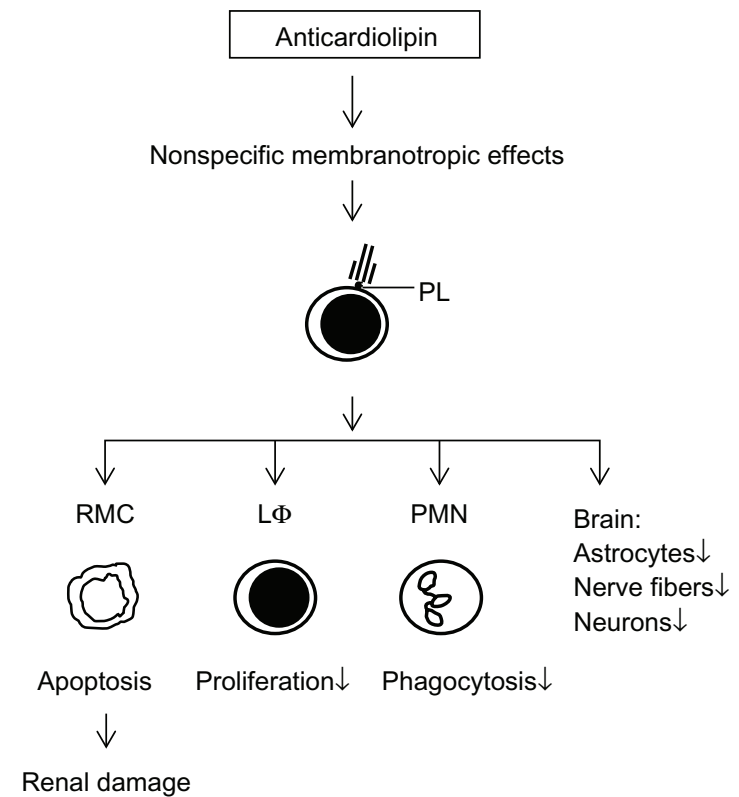

Figure 3 Schema depicting the immunopathogenic effects of anticardiolipin autoantibodies on immune responses.

Abbreviations: RMC, rat glomerular mesangial cells; PL, phospholipids; PMN, polymorphonuclear neutrophil; L $\Phi$, lymphocytes. monoclonal autoantibody also triggered immunosuppressive IL-10 overproduction via phosphatidylinositide 3-kinase (PI3 K)-dependent signaling pathways in lipopolysaccharideactivated macrophages. ${ }^{79}$ These diverse immunological effects likely implicate a role for antiribosomal $\mathrm{P}$ antibodies in lupus pathogenesis. ${ }^{76}$

In addition to antiribosomal $\mathrm{P}$ and anti-dsDNA, ${ }^{36}$ other autoantibodies are potentially involved in NPSLE, including antibodies against endothelial cells, ${ }^{77}$ neuronal NMDAreceptor subtypes $2 \mathrm{a}$ and $2 \mathrm{~b}$ (anti-NR2 antibodies), ${ }^{36}$ glial fibrillary acid protein, microtubule-associated protein 2 , and matrix metalloproteinase $9 .{ }^{80,81} \mathrm{~A}$ schema demonstrating the immunopathogenic effects of antiribosomal $\mathrm{P}$ antibodies on $\mathrm{T}$ cells and macrophages is shown in Figure 4.

\section{Immunopathological effects of anti-SSB/La autoantibodies on neutrophil functions}

Neonatal lupus erythematosus has a clinical spectrum of cutaneous, cardiac, and some systemic manifestations in newborn infants whose mother produces antibodies against intracellular soluble ribonucleoproteins $48 \mathrm{kDa} \mathrm{SSB} / \mathrm{La}, 52 \mathrm{kDa} \mathrm{SSA} /$ Ro, or $60 \mathrm{kDa} \mathrm{SSA} / \mathrm{Ro}^{82}$ However, only $1 \%-2 \%$ of mothers with these autoantibodies deliver neonates with lupus erythematosus, regardless of being healthy or symptomatic. ${ }^{83}$ Li et a ${ }^{84}$ used affinity-purified anti-SSB/La autoantibodies

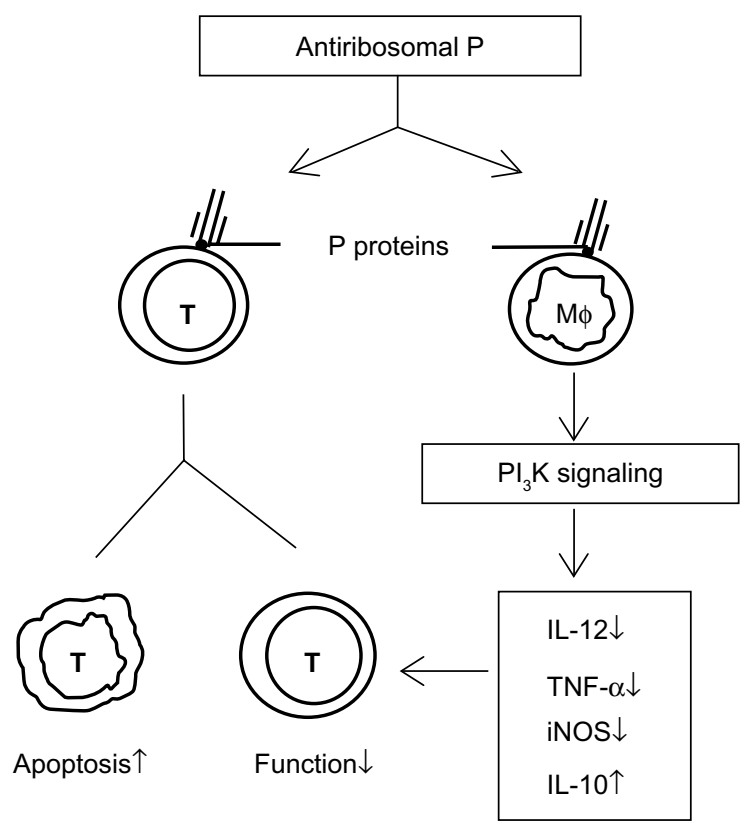

Figure 4 Schema depicting the immunopathogenic effects of antiribosomal P protein autoantibodies on brain and kidney damage and immune responses. Abbreviation: M $\phi$, macrophage cell line RAW264.7. 
from patients with SS to demonstrate a cross-reaction with cardiac sarcolemmal laminin. These data suggest that molecular mimicry between laminin and SSB/La exists. Anti-SSB/ La antibodies may play a crucial role in the pathogenesis of newborn congenital heart block. Reed et $\mathrm{al}^{85}$ further found that Ro60 requires $\gamma 3$ RNA for cell-surface exposure and inflammation in atrioventricular nodes, the cardiac conducting system, or the myocardium of neonatal lupus. In contrast, neutropenia and lymphocytopenia are hematological abnormalities in patients with SLE that are correlated with disease activity and are responsible for morbidity/mortality. ${ }^{86}$ Anti-SSB/La appeared in $87 \%$ of patients with primary SS in association with leukopenia and lymphopenia. ${ }^{87}$ Hsieh et al ${ }^{88}$ found that anti-SSB/La antibodies purified from active SLE sera were able to penetrate into cells responsible for neutropenia and functionally impair PMNs via activation-induced cell apoptosis. Subsequently, Biswas et $\mathrm{l}^{89}$ confirmed that the presence of anti-SSB/La was associated with defective neutrophil phagocytosis in patients with SLE. In addition, anti-SSB/La antibodies were shown to promote TNF- $\alpha$ secretion from macrophages..$^{90}$ Increased apoptosis superimposed on defective clearance of apoptotic cells rendered the released chromatins from PMN apoptotic blebs to be more immunogenic. These denatured chromatin molecules were finally taken-up by myeloid dendritic cells, which bound to endosomal TLR3, TLR7, and TLR9. These three TLRs are endosomal receptors for binding with dsRNA, ssRNA and dsDNA for immune reactions. In addition to apoptotic blebs, neutrophil extracellular traps (NETs) released from dying neutrophils in a process called NETosis may be a major source of autoantigens. Overactive NETosis may become a source in lupus pathogenesis. ${ }^{91,92}$ Obviously, anti-SSB/La autoantibodies play a crucial role in overactive NETosis. The immunopathogenic effects of anti-SSB/La autoantibodies on lupus pathogenesis are illustrated in Figure 5.

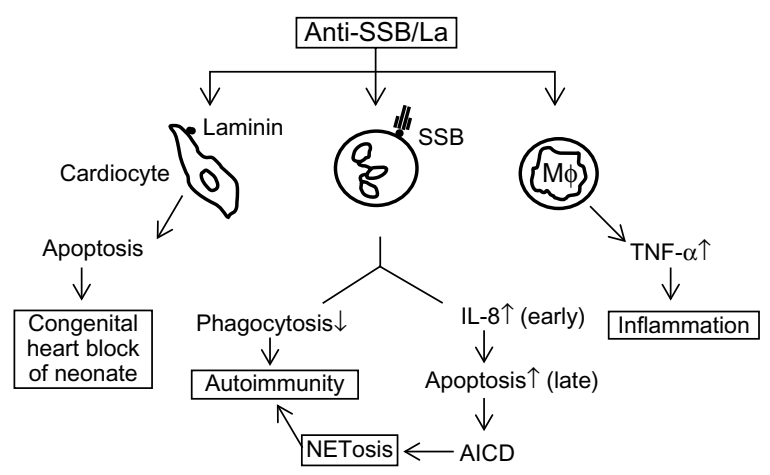

Figure $\mathbf{5}$ Schema depicting the effects of anti-SSB/La autoantibodies on neutrophil and macrophage functions, and autoimmunity.

Abbreviations: AICD, activation-induced cell death (apoptosis); NETosis, neutrophil extracellular traps release.
In a recent study, Wu et al (unpublished data) found that exogenous SSB/La per se or SSB/La-anti-SSB/La ICs could potently activate IL- 8 production and phagocytosis of $\mathrm{PMNs}$ as well as anti-SSB/La autoantibodies through PI3 $\mathrm{K}$ and MAPK signaling pathways. It was concluded that the SSB/ La-anti-SSB/La system may play a complex role in autoimmune pathogenesis.

\section{Conclusion}

Breakdown of self-tolerance to nuclear antigens and polyclonal B-cell activation render the production of a number of autoantibodies in patients with SLE. Some of these autoantibodies, such as anti-dsDNA, antiribosomal P, anticardiolipin, and anti-SSB/La, are indeed pathogenic, as they bind to surface-expressed cross-reactive antigens through electrostatic interactions or establish nonspecific Fc $\gamma \mathrm{R}$ binding to allow penetration into the cell's interior. These pathogenic autoantibodies not only directly damage the tissues to promote the release of more nuclear antigens, but derail innate and adaptive immune functions. The vicious cycle caused by these pathogenic autoantibodies sustains the chronic immunological and inflammatory abnormalities in patients with SLE.

\section{Acknowledgments}

This work was supported by a grant from the National Science Council (NSC99-2628-B-002-020-MY3). We are indebted to the Clinical Immunology and Transplantation Research Center, Department of Medical Research, National Taiwan University Hospital, for providing research space and facilities.

\section{Disclosure}

The authors report no conflicts of interest in this work.

\section{References}

1. ShererY, Gorstein A, Fritzler MJ, Shoenfeld Y. Autoantibodies explosion on systemic lupus erythematosus: more than 100 different antibodies found in SLE patients. Semin Arthritis Rheum. 2004;35(2):501-537.

2. Schroeder K, Herrmann M, Winkler TH. The role of somatic hypermutation in the generation of pathogenic antibodies in SLE. Autoimmunity. 2013;46(2):121-127.

3. Wardemann H, Yurasov S, Schaefer A, Young JW, Meffre E, Nussenzweig MC. Predominant autoantibody production by early human B cell precursors. Science. 2003;301(5639):1374-1377.

4. Munoz LE, Lauber K, Schiller M, Manfredi AA, Hessrnann M. The role of defective clearance of apoptotic cells in systemic autoimmunity. Nat Rev Rheumatol. 2010;6(5):280-289.

5. Waisman A, Mendlovic S, Ruiz PJ, Zinger H, Meshores A, Mozes E. The role of the 16/6 idiotype network in the induction and manifestations of systemic lupus erythematosus. Int Immunol. 1993;5(10): 1293-1300.

6. Yurasov S, Wardemann H, Hammersen J, et al. Defective B cell tolerance in systemic lupus erythematosus. J Exp Med. 2005;201(5): 703-711. 
7. Routsias JG, Tzioufas AG. B-cell epitopes of intracellular autoantigens $\mathrm{Ro} / \mathrm{SSA}$ and $\mathrm{La} / \mathrm{SSB}$ : tools to study the regulation of autoimmune response. J Autoimmun. 2010;35(3):256-264.

8. Routsias JG, Vlachroyiannopoulous PG, Tzioufas AG. Autoantibodies to intracellular autoantigens and their B-cell epitopes: molecular probes to study the autoimmune response. Crit Rev Clin Lab Sci. 2006;43(3): 203-248.

9. Pickering MC, Botto M, Taylor PR, Lawchmann PJ, Walport MJ. Systemic lupus erythematosus complement deficiency and apoptosis. Adv Immunol. 2000;76:227-324.

10. Sjöwall C, Wetlero J. Pathogenic implications for autoantibodies against C-reactive protein and other acute phase proteins. Clin Chim Acta. 2007;378(1-2):13-23.

11. Dhillon V, Latchman D, Isenberg D. Heat shock proteins and systemic lupus erythematosus. Lupus. 1991;1(1):3-8.

12. Prabhakar BS, Saegusa J, Onodera T, Notkins AL. Lymphocytes capable of making monoclonal autoantibodies that react with multiple organs are a common feature of the normal B cell repertoire. J Immunol. 1984;133(6):2815-2817.

13. Hurez V, Dietrich G, Kaveir SV, Kazatchkine MD. Polyreactivity is a property of natural and disease-associated human autoantibodies. Scand J Immunol. 1993:38(2):190-196.

14. Zhang J, Jacobi AM, Wang T, Berlin RA, Volpe BT, Diamond B. Polyreactive autoantibodies in systemic lupus erythematosus have pathogenic potential. J Autoimmun. 2009;33(3-4):270-274.

15. Dimitrov JD, Pashov AD, Vassilev TL. Antibody polyspecificity: what does it matter? In: Lutz HU, editor. Naturally Occurring Antibodies (NAbs). Heidelberg: Springer; 2012.

16. Ruiz-Argüelles A, Rivadeneyra-Espinoza L, Alarcón-Segovia D. Antibody penetration into living cells: pathogenic, preventive and immuno-therapeutic implications. Curr Pharm Des. 2003;9(23): 1881-1887.

17. Martin T, Crouzier R, Weber JC, Kipps TJ, Pasquali JL. Structurefunction studies on a polyreactive (natural) autoantibody. Polyreactivity is dependent on somatically generated sequence in the third complementarity-determining region of the antibody heavy chain. J Immunol. 1994;152(12):5988-5996.

18. Ditzel HJ, Itoh K, Burton DJ. Determinants of polyreactivity in a large panel of recombinant human antibodies from HIV-1 infection. J Immunol. 1996;157(2):739-749.

19. James LC, Tawfik DS. The specificity of cross-reactivity: promiscuous antibody binding involves specific hydrogen bonds rather than non-specific hydrophobic stickiness. Protein Sci. 2003;12(10): 2183-2193.

20. Weller S, Conde C, Knapp AM, et al. Autoantibodies in mice lacking terminal deoxynucleotidyl transferase: evidence for a role of $\mathrm{N}$ region addition in the polyreactivity and in the affinity of anti-DNA antibodies. J Immunol. 1997;159(8):3890-3898.

21. Alarcón-Segovia D, Llorente L, Ruíz-Argüelles A. The penetration of autoantibodies into cells may induce tolerance to self by apoptosis of autoreactive lymphocytes and cause autoimmune disease by dysregulation and/or cell damage. J Autoimmun. 1996;9(2):295-300.

22. Ruíz-Argüelles A, Pérez-Romano B, Llorente L, Alarcón-Segovia D, Castellanos JM. Penetration of anti-DNA antibodies into mature live cells. J Autoimmun. 1998;11(5):547-556.

23. Kurien BT, Scofield RH. Autoantibody determination in the diagnosis of systemic lupus erythematosus. Scand J Immunol. 2006;64(3): 227-235.

24. Liu CC, Ahearn JM. The search for lupus biomarkers. Best Pract Res Clin Rheumatol. 2009;23(4):507-523.

25. Ahearn JM, Liu CC, Kao AH, Manzi S. Biomarkers for systemic lupus erythematosus. Transl Res. 2012;159(4):326-342.

26. Rekvig OP, Putterman C, Casu C, et al. Autoantibodies in lupus: culprits or passive bystanders? Autoimmun Rev. 2012:11(8):596-603.

27. Zhen QL, Xie C, Wu T, et al. Identification of autoantibody clusters that best predict lupus disease activity using glomerular proteome arrays. J Clin Invest. 2013;115(15):3428-3439.
28. Hockberg MC. Updating the American College of Rheumatology revised criteria for the classification of systemic lupus erythematosus. Arthritis Rheum. 1997;40(9):1725.

29. Bizzaro N, Villalta D, Giavarina D, Tozzoli R. Are anti-nucleosome antibodies a better diagnostic marker than anti-dsDNA antibodies in systemic lupus erythematosus? A systemic view and a study of metanalysis. Autoimmu Rev. 2012;12(2):97-106.

30. Weisbart RH, Garrett RA, Liebling MR, Barnett EV, Paulus HE, Katz DH. Specificity of anti-nucleoside antibodies in systemic lupus erythematosus. Clin Immunol Immunopathol. 1983;27(3): 403-411.

31. Bambardier C, Gladman DD, Urowitz MB, Caron D, Chang CH. Derivation of the SLEDAI. A disease activity index for lupus patients. The Committee on Prognosis Studies in SLE. Arthritis Rheum. 1992;35(6):630-640.

32. Symmons DP, Coppock JS, Bacon PA, et al. Development and assessment of a computerized idea of clinical disease activity in systemic lupus erythematosus. Members of the British Isles Lupus Assessment Group (BILAG). QJ Med. 1998;79(1):927-937.

33. Natali S, Karim MY. Autoantibodies as markers for detecting concurrent disease activity in systemic lupus erythematosus. Transl Res. 2010;156(6):317-319.

34. Flierman R, Daha MR. Pathogenic role of anti-C1q autoantibodies in the development of lupus nephritis - a hypothesis. Mol Immunol. 2007;44(1-3):133-138.

35. Pickering $\mathrm{M}$, Botto $\mathrm{M}$. Are anti-C1q antibodies different from other SLE autoantibodies? Nat Rev Rheumatol. 2010;6(8):490-493.

36. Diamond B, Volpe BT. A model for lupus brain disease. Immunol Rev. 2012;248(1):56-67.

37. Seret G, Le MeurY, Renaudineau Y, Youinou P. Mesangial cell-specific antibodies are central to the pathogenesis of lupus nephritis. Clin Dev Immunol. 2012;2012:579670.

38. Satoh M, Vázquez-Del Mercado M, Chan EKL. Clinical interpretation of antinuclear antibody tests in systemic rheumatic diseases. Mod Rheumatol. 2009;19(3):219-228.

39. Hanly JG, Thompson K, McCurdy G, Fougere L, Thercault C, Wilton K. Measurement of autoantibodies using multiplex methodology in patients with systemic lupus erythematosus. J Immunol Methods. 2010;352(1-2):147-153.

40. Kim Y, Park Y, Lee EY, Kim HS. Comparison of automated multiplexed bead-based ANA screen assay with ELISA for detecting five common anti-extractable nuclear antigens and anti-dsDNA in systemic lupus erythematosus. Clin Chim Acta. 2012;413(1-2):308-311.

41. Eriksson C, Kokkonen H, Johansson H, Hallmans G, Wadell G, Rantapää-Dahlqvist S. Autoantibodies predate the onset of systemic lupus erythematosus in northern Sweden. Arthritis Res Ther. 2011; 13(1):R30.

42. Yu CL, Chang KL, Chiu CC, Chiang BN, Han SH, Wang SR. Alteration of mitogenic responses of mononuclear cells by anti-dsDNA antibodies resembling immune disorders in patients with systemic lupus erythematosus. Scand J Rheumatol. 1989;18(5):265-276.

43. Tsai CY, Wu TH, Sun KH, Yu CL. Effects of antibodies to double stranded DNA, purified from serum samples of patients with active systemic lupus erythematosus, on the glomerular mesangial cells. Ann Rheum Dis. 1992;51(2):162-167.

44. Sun KH, Liu WT, Tsai CY, Tang SJ, Han SH, Yu CL. Anti-dsDNA antibodies cross-react with ribosomal $\mathrm{P}$ proteins expressed on the surface of glomerular mesangial cells to exert a cytostatic effect. Immunology. 1995;85(2):262-269.

45. Du H, Chen M, Zhang Y, Zhao MH, Wang HY. Cross-reaction of antiDNA autoantibodies with membrane proteins of human glomerular mesangial cells in sera from patients with lupus nephritis. Clin Exp Immunol. 2006;145(1):21-27.

46. Yung S, Zhang Q, Zhang CZ, Chan KW, Lui SL, Chan TM. Anti-DNA antibody induction of protein kinase $\mathrm{C}$ phosphorylation and fibronectin synthesis in human and murine lupus and the effect of mycophenolic acid. Arthritis Rheum. 2009;60(7):2071-2082. 
47. Yung S, Cheung KF, Zhang Q, Chan YM. Anti-DNA antibodies bind to mesangial annexin II in lupus nephritis. J Am Soc Nephrol. 2010;21(11):1912-1927.

48. Fenton KA, Tommeras B, Marion TN, Rekvig OP. Pure anti-daDNA $\mathrm{mAbs}$ need chromatin structures to promote glomerular mesangial deposits in BALB/c mice. Autoimmunity. 2010;43(2):179-188.

49. Sun KH, Liu WT, Tang SJ, et al. The expression of acidic ribosomal phosphoproteins on the surface membrane of different tissues in autoimmune and normal mice which are the target molecules for antidouble-stranded DNA antibodies. Immunology. 1996;87(3):362-371.

50. Sun KH, Hong CC, Tang SJ, et al. Anti-dsDNA autoantibody crossreacts with the $\mathrm{C}$-terminal hydrophobic cluster region containing phenylalanines in the acidic ribosomal phosphoprotein P1 to exert a cytostatic effect on the cells. Biochem Biophys Res Commun. 1999;263(2): 334-339.

51. Yu CL, Sun KH, Tsai CY, Hsieh SC, Yu HS. Anti-dsDNA antibody up-regulates interleukin-6, but not cyclooxygenase, gene expression in glomerular mesangial cells: a marker of immune-mediated renal damage? Inflamm Res. 2001;50(1):12-18.

52. Hsieh SC, Sun KH, Tsai CY, et al. Monoclonal anti-double stranded DNA antibody is a leukocyte binding protein to up-regulate interleukin- 8 gene expression and elicit apoptosis of normal human polymorphonuclear neutrophils. Rheumatology (Oxford). 2001;40(8):851-858.

53. Luan HY, Tang SJ, Yang W, Tsai CY, Sun GH, Sun KH. Monoclonal anti-double-stranded DNA antibodies cross-react with phosphoglycerate kinase 1 and inhibit the expression and production of IL-2 in activated Jurkat T cell line. Clin Immunol. 2006;120(3):326-334.

54. Song YC, Tang SJ, Lee TP, et al. Reversing interleukin-2 inhibition mediated by anti-double-stranded DNA autoantibody ameliorates glomerulonephritis in MRL-lpr/lpr mice. Arthritis Rheum. 2010;62(8): 2401-2411.

55. Lee TP, Tang SJ, Wu MF, Song YC, Yu CL, Sun KH. Transgenic overexpression of anti-double-stranded DNA autoantibody and activation of Toll-like receptor 4 in mice induce severe systemic lupus erythematosus. J Autoimmun. 2010;35(4):358-367.

56. Song YC, Sun GH, Lee TP, et al. Arginines in the CDR of anti-dsDNA autoantibodies facilitate cell internalization via electrostatic interactions. Eur J Immunol. 2008;38(11):3178-3190.

57. Lisi S, Sisto M, Lofrumento DD, D'Amore S, D'Amore M. Advances in the understanding of the Fc gamma receptors-mediated autoantibodies uptake. Clin Exp Med. 2011;11(1):1-10.

58. Carreras LO, Defreyn G, Machin SJ, et al. Arterial thrombosis, intrauterine death and lupus anticoagulant: detection of immunoglobulin interfering with prostacyclin formation. Lancet. 1981;317(8214): 244-246.

59. Hughes GR. Thrombosis, abortion, cerebral disease, and the lupus coagulant. Br Med J (Clin Res Ed). 1983;287(8):1088-1089.

60. Harris EN, Gharavi AE, Asherson RA, Boey ML, Hughes GR. Cerebral infarction in systemic lupus: association with anticardiolipin antibodies. Clin Exp Rheumatol. 1984;2(1):47-51.

61. Hamsten A, Norberg R, Björkholm M, DeFaire U, Holm G. Antibodies to cardiolipin in young survivors of myocardial infarction: an association with recurrent cardiovascular events. Lancet. 1986;1(8473): $113-115$.

62. Englert HJ, Derue GM, Loizou S, et al. Pregnancy and lupus: prognostic indicators and response to treatment. $Q J$ Med. 1988;66(250): 125-136.

63. Alarcón-Segovia D, Cardiel MH, Reyes E. Antiphospholipid arterial vasculopathy. J Rheumatol. 1989;16(5):762-767.

64. Arad A, Proulle V, Furie RA, Furie BC, Furie B. $\beta 2$-Glycoprotein-1 autoantibodies from patients with antiphospholipid syndrome are sufficient to potentiate arterial thrombus formation in a mouse model. Blood. 2011;117(12):3453-3459.

65. Vista ES, Crowe SR, Thompson LF, et al. Influenza vaccination can induce new-onset anticardiolipins but not $\beta 2$-glycoprotein-I antibodies among patients with systemic lupus erythematosus. Lupus. 2012;21(2): $168-174$.
66. Cederholm A, Frostegard J. Annexin A5 in cardiovascular disease and systemic lupus erythematosus. Immunobiology. 2005;210(10): 761-768.

67. Frostegård AG, Su J, Landenberg P, Frostegård J. Effects of anticardiolipin antibodies and IVIG on annexin A5 binding to endothelial cells: implications for cardiovascular disease. Scand J Rheumatol. 2010;39(1):77-83.

68. Lin WS, Chen PC, Yang CD, et al. Some antiphospholipid antibodies recognize conformational epitopes shared by beta2-glycoprotein I and the homologous catalytic domains of several serine proteases. Arthritis Rheum. 2007;56(5):1638-1647.

69. Moroni PL, Borghi OB, Raschi E, Tedesco F. Pathogenesis of antiphospholipid syndrome: understanding the antibodies. Nat Rev Rheumatol. 2011;7(6):330-339.

70. Misra R, Venables PJ, Plater-Zyberk C, Watkins PF, Maini RN. Anti-cardiolipin antibodies in infectious mononucleosis react with the membrane of activated lymphocytes. Clin Exp Immunol. 1989;75(1): $35-40$.

71. Yu CL, Sun KH, Tsai CY, Wang SR. Inhibitory effects of anticardiolipin antibodies on lymphocyte proliferation and neutrophil phagocytosis. Ann Rheum Dis. 1991;50(12):903-908.

72. Sun KH, Liu WT, Tsai CY, Liao TS, Lin WM, Yu CL. Inhibition of astrocyte proliferation and binding to brain tissue of anticardiolipin antibodies purified from lupus serum. Ann Rheum Dis. 1992;51(6): 707-712.

73. Tsai CY, Yu CL, Wu TH, et al. Polyclonal anticardiolipin antibodies purified from sera of patients with active systemic lupus erythematosus induce apoptosis of the cultured glomerular mesangial cells. Scand J Rheumatol. 2000;29(6):370-379.

74. Bonfa E, Golombek SJ, Kaufman LD, et al. Association between lupus psychosis and anti-ribosomal P protein antibodies. $N$ Engl J Med. 1987;317(15):265-271.

75. Martin AL, Reichlin M. Fluctuations of antibody to ribosomal P proteins correlate with appearance and remission of nephritis in SLE. Lupus. 1996;5(1):22-29.

76. Toubi E, ShoenfeldY. Clinical and biological aspects of anti-P-ribosomal protein autoantibodies. Autoimmun Rev. 2007;6(3):119-125.

77. Sun KH, Tang SJ, Lin ML, Wang YS, Sun GH, Liu WT. Monoclonal antibodies against ribosomal $\mathrm{P}$ proteins penetrate into living cells and cause apoptosis of Jurkat T cells in culture. Rheumatology (Oxford). 2001;40(7):750-756.

78. Sun KH, Tang SJ, Chen CY, et al. Monoclonal ribosomal P autoantibody inhibits the expression and release of IL-12, TNF-alpha and iNOS in activated RAW macrophage cell line. J Autoimmun. 2005;24(2): $135-143$.

79. Lee TP, Leu SJ, Huang JC, et al. Anti-ribosomal phosphoprotein autoantibody triggers interleukin-10 overproduction via phosphatidylinositol 3-kinase-dependent signalling pathways in lipopolysaccharide-activated macrophages. Immunology. 2009;127(1):91-102.

80. Lauvsnes MB, Omdal R. Systemic lupus erythematosus, the brain and anti-NR2 antibodies. J Neurol. 2012;259(4):622-629.

81. Efthimiou P, Blanco M. Pathogenesis of neuropsychiatric systemic lupus erythematosus and potential biomarkers. Mod Rheumatol. 2009;19(4):457-468.

82. Buyon JP, Clancy RM. Neonatal lupus syndrome. Curr Opin Rheumatol. 2003;15(5):535-541.

83. Hon KL, Leung AK. Neonatal lupus erythematosus. Autoimmun Dis. 2012;2012:301274

84. Li JM, Horsfall AC, Maini RN. Anti-La (SS-B) but not anti-Ro (SS-A) antibodies cross-react with laminin - a role in the pathogenesis of congenital heart block? Clin Exp Immunol. 1995;99(3):316-324.

85. Reed JH, Sim S, Wolin SL, Clancy RM, Buyon JR. Ro60 requires y3RNA for cell surface exposure and inflammation associated with cardiac manifestation of neonatal lupus. J Immunol. 2013;192(1):110-116.

86. Starkebaum G, Price TH, Lee PM, Arend WP. Autoimmune neutropenia in systemic lupus erythematosus. Arthritis Rheum. 1978;21(5): 504-512. 
87. Peng SL, Graft J. Antinuclear antibodies. In: Ruddy S, editor. Kelley's Textbook of Rheumatology. Philadelphia: WB Sanders; 2001:167-171.

88. Hsieh SC, Yu HS, Lin WW, et al. Anti-SSB/La is one of the antineutrophil autoantibodies responsible for neutropenia and functional impairment of polymorphonuclear neutrophils in patients with systemic lupus erythematosus. Clin Exp Immunol. 2003;131(3):506-516.

89. Biswas D, Mathias A, Dayal R, Aggarwal A, Misra R, Naik S. Presence of antibodies to SSB/La is associated with decreased phagocytic efficiency of neutrophils in patients with systemic lupus erythematosus. Clin Rheumatol. 2008;27(6):717-722.

90. Minada-Carús ME, Askanase AD, Clancy RM, et al. Anti-SSA/Ro and anti-SSB/La autoantibodies bind to the surface of apoptotic fetal cardiocytes and promote secretion of TNF-alpha by macrophages. J Immunol. 2000;165(9):5345-5351.
91. Bouts YM, Wolthues DF, Dirks MF, et al. Apoptosis and NET formation in the pathogenesis of SLE. Autoimmunity. 2012;45(8):597-601.

92. Knight JS, Kaplan MJ. Lupus neutrophils: 'NET' gain in understanding lupus pathogenesis. Curr Opin Rheumatol. 2012;24(5):441-450.

93. Hanrotel-Saliou C, Segalen I, Meur YL, Youinou P, Renaudineau Y. Glomerular antibodies in lupus nephritis. Clin Rev Allergy Immunol. 2011;40(3):151-158.

94. Faaber P, Capel PJA, Riike GPM, Vierwinden G, van de Putte LBA, Koene RAP. Cross-reactivity of anti-DNA antibodies with proteoglycan. Clin Exp Immunol. 1984;55(3):502-508.

95. Yang HB, Zheng WJ, Zhang X, Tang FL. Induction of endothelial cell apoptosis by anti-alpha-enolase antibody. Chin Med Sci J. 2011;26(3): $152-157$.

\section{Publish your work in this journal}

Current Biomarker Findings is an international, peer-reviewed, open access journal publishing original research, reports, reviews and commentaries on all areas of biomarker research. The manuscript management system is completely online and includes a very quick and fair

\section{Dovepress}

peer-review system. Visit http://www.dovepress.com/testimonials.php to read real quotes from published authors. 